\title{
Cardiosphere-derived cells do not improve cardiac function in rats with cardiac failure
}

Taís Hanae Kasai-Brunswick 1,2, , Andréa Rodrigues da Costa2, Raiana Andrade Quintanilha Barbosa 1,2, Bruna Farjun ', Fernanda Cristina Paccola Mesquita', Danúbia Silva dos Santos ${ }^{1}$, Isalira Peroba Ramos ${ }^{1,3}$, Grazielle Suhett', Guilherme Visconde Brasil', Sandro Torrentes da Cunha', José Oscar R. Brito², Juliana do Amaral Passipieri ${ }^{1,2}$, Adriana Bastos Carvalho ${ }^{1,4}$ and Antonio Carlos Campos de Carvalho 1,2,3,4*

\begin{abstract}
Background: Heart failure represents an important public health issue due to its high costs and growing incidence worldwide. Evidence showing the regenerative potential of postmitotic heart tissue has suggested the existence of endogenous cardiac stem cells in adult hearts. Cardiosphere-derived cells (CDC) constitute a candidate pool of such cardiac stem cells. Previous studies using acute myocardial infarction (MI) models in rodents demonstrated an improvement in cardiac function after cell therapy with CDC. We evaluated the therapeutic potential of CDC 60 days after $\mathrm{Ml}$ in a rat model.

Methods: CDC were obtained from human discarded myocardial tissue and rat hearts by enzymatic digestion with collagenase II. At 10-15 days after isolation, small, round, phase-bright cells (PBCs) appeared on top of the adherent fibroblast-like cells. The PBCs were collected and placed on a nonadherent plate for 2 days, where they formed cardiospheres which were then transferred to adherent plates, giving rise to CDC. These CDC were characterized by flow cytometry. Wistar rats were submitted to $\mathrm{Ml}$ through permanent occlusion of the anterior descending coronary artery. After 60 days, they were immunosuppressed with cyclosporine A during 10 days. On the third day, infarcted animals were treated with $5 \times 10^{5}$ human $C D C$ (hCDC) or placebo through intramyocardial injection guided by echocardiogram. Another group of animals was treated with rat CDC (rCDC) without immunosuppression. hCDC and rCDC were stably transduced with a viral construct expressing luciferase under control of a constitutive promoter. CDC were then used in a bioluminescence assay. Functional parameters were evaluated by echocardiogram 90 and 120 days after $\mathrm{Ml}$ and by Langendorff at 120 days.

Results: CDC had a predominantly mesenchymal phenotype. Cell tracking by bioluminescence demonstrated over 85\% decrease in signal at 5-7 days after cell therapy. Cardiac function evaluation by echocardiography showed no differences in ejection fraction, end-diastolic volume, or end-systolic volume between groups receiving human cells, rat cells, or placebo. Hemodynamic analyses and infarct area quantification confirmed that there was no improvement in cardiac remodeling after cell therapy with CDC.
\end{abstract}

Conclusion: Our study challenges the effectiveness of CDC in post-ischemic heart failure.

Keywords: Cell therapy, Myocardial infarction, Heart failure, Stem cells, Cardiosphere-derived cells, Bioluminescence

\footnotetext{
* Correspondence: acarlos@biof.ufrj.br

${ }^{1}$ Institute of Biophysics Carlos Chagas Filho, Federal University of Rio de

Janeiro, Av. Carlos Chagas Filho, n³73, room G2-053, CEP:21941-902 Rio de

Janeiro, RJ, Brazil

${ }^{2}$ National Institute of Cardiology, Rua das Laranjeiras, n³74-Laranjeiras,

CEP:22240-006 Rio de Janeiro, RJ, Brazil

Full list of author information is available at the end of the article
} 


\section{Background}

Heart failure (HF) represents an important public health issue due to its high costs and growing incidence worldwide. An ageing population and the increased survival rate of patients suffering coronary events contribute to aggravate this scenario [1]. Pharmacological therapy only attenuates disease progression, and patients in advanced stages of HF require heart transplantation, a treatment option that is compromised by the shortage of organs.

Recent evidence showing the regenerative potential of postmitotic heart tissue suggested the existence of a pool of endogenous cardiac stem cells in adult hearts [2]. Since then, the scientific community has dedicated enormous effort to the identification and isolation of these cells [3-5], which may ultimately provide an alternative therapy in the treatment of cardiac disease.

Cardiosphere-derived cells (CDC) constitute a candidate pool of such cardiac stem cells. CDC comprise a heterogeneous population of cardiac cells, including a potentially clonogenic stem cell subpopulation [6]. Several studies have proposed that CDC have cardiomyogenic differentiation potential in vitro [6-9]. Furthermore, infarcted animals treated with CDC showed improvement in cardiac function, reduced scar size, and increased viability of the myocardium when compared with placebo-treated animals $[6,7,10-12]$.

However, work utilizing lineage-tracing has demonstrated that CDC failed to differentiate into cardiomyocytes in vivo [13] and that cell therapy did not improve cardiac function in murine infarct models [13, 14]. In addition, other authors have questioned the differentiation potential of CDC in vitro [15]. Despite existing controversies about the therapeutic applicability of CDC in animal models, these cells have already entered a phase I clinical trial (CADUCEUS) [16]. Results from the trial, after a 1-year follow-up, described a subtle enhancement in the viability of cardiac muscle without benefit to cardiac function [17]. A meta-analysis of several cardiac clinical trials, including CADUCEUS, showed that cell therapy provided no benefit in terms of left ventricular function [18].

In light of this controversy, we evaluated the therapeutic potential of cell treatment with $\mathrm{CDC}$ in a rat model of HF. We demonstrate that treatment with rat CDC (rCDC) or human CDC (hCDC) did not improve cardiac function in rats, and we propose that further studies utilizing animal models are needed before this new therapeutic alternative can be efficaciously applied to humans.

\section{Methods}

\section{Human samples}

Human myocardial tissue was obtained from the National Institute of Cardiology (Brazil). Right atrial appendages, routinely discarded from patients undergoing coronary artery bypass grafting (CABG), were collected and used for cell isolation.

\section{Animals}

Two-month-old Wistar rats weighing 200 g were used in this study. The animals were maintained in cages with food and water ad libitum and $12 \mathrm{~h} / 12 \mathrm{~h}$ light/dark cycle.

\section{Cell isolation}

Briefly, human discarded myocardial tissue or rat hearts were fractionated into small pieces $\left(1 \mathrm{~mm}^{3}\right)$ and digested using collagenase type II $(200 \mathrm{IU} / \mathrm{ml})$. Samples were submitted to 5-7 cycles of digestion for $5 \mathrm{~min}$ at $37{ }^{\circ} \mathrm{C}$ under gentle agitation. Cells were plated using the following culture medium: Ham's F12 supplemented with $10 \%$ fetal bovine serum, $1 \%$ penicillin/streptomycin, $10 \mathrm{ng} / \mathrm{ml}$ of basic fibroblast growth factor (bFGF), 0.005 $\mathrm{U} / \mathrm{ml}$ of erythropoietin, and $0.2 \mathrm{mM}$ of glutathione. Leukemia inhibitory factor (LIF) $(10 \mathrm{ng} / \mathrm{ml})$ was added in the case of rat CDC. After 15 days, phase-bright cells (PBCs) were collected using phosphate buffer saline (PBS) at $4{ }^{\circ} \mathrm{C}$. PBCs were cultured using the same medium on nonadherent plates, resulting in the formation of cardiospheres. After 2 days, cardiospheres were collected and placed on adherent plates, giving rise to CDC. Cells were expanded for at least three passages before the experiments.

\section{Flow cytometry}

CDC were dissociated using a nonenzymatic solution and blocked in PBS with $0.5 \%$ bovine serum albumin (BSA) and $\mathrm{Fc}$ receptor blocking reagent (BD Biosciences) for $20 \mathrm{~min}$ at $4{ }^{\circ} \mathrm{C}$. Cells were then stained, using the same solution, with the following antibodies: hCDC-CD105, CD90, CD73, CD44, CD166, CD54, CD146, CD45, CD19, CD14, CD34, CD31, CD33, CD133, and CD117 (all from BD Pharmingen); rCDC-CD90 (eBiosciences), CD29, CD11b (BD Pharmingen), and CD45RA (Caltag). Data were acquired in BD FACSCanto II or BD FACSAria IIu and analyzed using FlowJo version $\mathrm{X}$.

\section{Echocardiography}

Echocardiography was performed using the Vevo 770 High-Resolution Imaging System (VisualSonics) under isoflurane anesthesia. Images were acquired in bidimensional mode and analyzed by a blinded investigator. Left ventricular end-diastolic volume (EDV), end-systolic volume (ESV), ejection fraction (EF), and fractional area change (FAC) were calculated using Simpson's method. In brief, these parameters of cardiac function were evaluated in a long parasternal axis view and four hightemporal resolution B-mode short-axis images, taken at different ventricular levels, as described previously [19]. 
Examinations were performed before myocardial infarction (MI), 1 day before cell injection, and 60 and 90 days after cell injection.

\section{Myocardial infarction and cell injection}

Animals were anesthetized with $80 \mathrm{mg} / \mathrm{kg}$ of ketamine and $20 \mathrm{mg} / \mathrm{kg}$ of xylazine and placed under positive pressure ventilation. After thoracotomy, the heart was exposed and the left anterior descending (LAD) coronary artery was ligated using 6-0 Prolene suture. The chest was closed and the animals were carefully removed from ventilation support. Sham-operated rats were submitted to an identical procedure except for LAD ligation. MI was confirmed by electrocardiography (ECG). Infarcted animals were included in the study only if the EF was below $45 \%$.

Sixty days after MI, $5 \times 10^{5} \mathrm{CDC}$ were delivered to the myocardium using echocardiogram-guided injection. Cells were injected using a $29 \mathrm{G}$ needle into two regions of the infarct border zone $\left(2.5 \times 10^{5}\right.$ cells/injection $)$. The placebo-treated group received only vehicle, which was $25 \%$ Matrigel $^{\circ}$ (Corning) in Ham's F12. In the case of the $\mathrm{hCDC}$ group and the corresponding placebo group, immunosuppression with cyclosporine A was started 2 days before cell injection at a dose of $10 \mathrm{mg} / \mathrm{kg} / \mathrm{day}$ [20] and maintained for 10 days. In order to evaluate the quality of cells before injections, viability was analyzed using Trypan Blue Solution $0.4 \%$. More than $95 \%$ of the cells were viable before injection.

\section{Bioluminescence}

CDC were transduced with Luciferase 2 using a lentiviral vector as described previously [21]. To validate our injection method, hCDC and rCDC were stably transduced with luciferase 2 for in-vivo tracking. Cell tracking of CDC-Luc2 was performed after intramyocardial injection guided by echocardiogram. The groups of animals used for cardiac function evaluation received nontransduced CDC instead. In-vivo bioluminescence studies were conducted using the IVIS Lumina Imaging System (Xenogen Corporation) after intraperitoneal injection of $150 \mathrm{mg} / \mathrm{kg}$ of D-Luciferin (Caliper Life Sciences). Animals were imaged from the first day after CDC injection until the luminescent signal reached the lower limit of detection for the equipment (600 counts). Analyses were performed using Living Image software version 3.2.

\section{Langendorff perfusion experiments}

Animals received $5 \mathrm{IU} / \mathrm{g}$ of heparin by intraperitoneal injection and were euthanized. Hearts were removed by extended sternotomy and cannulated through the ascending aorta. The mechanical function was preserved using retrograde perfusion (at $10 \mathrm{ml} / \mathrm{min}$ with a peristaltic pump) with Krebs-Henseleit solution $(\mathrm{NaCl} 118 \mathrm{mM}, \quad \mathrm{KCl}$
$4.7 \mathrm{mM}, \mathrm{NaHCO}_{3} 25 \mathrm{mM}, \mathrm{KH}_{2} \mathrm{PO}_{4} 1.2 \mathrm{mM}, \mathrm{MgSO}_{4}$ $1.2 \mathrm{mM}$, glucose $11 \mathrm{mM}$, and $\mathrm{CaCl}_{2} 1.25 \mathrm{mM}$ ) in a modified Langendorff system. This physiological saline solution was maintained at $37^{\circ} \mathrm{C}$ and bubbled with carbogenic gas mixture $\left(95 \% \mathrm{O}_{2}, 5 \% \mathrm{CO}_{2}\right)$ for oxygenation and maintenance of $\mathrm{pH}$ at 7.4. A small latex balloon attached to a pressure transducer (MLT0380; ADInstruments) was inserted into the left ventricle. The balloon volume was increased until $0 \mathrm{mmHg}$ of initial diastolic pressure was obtained and then $20 \mu \mathrm{L}$ of solution was added every $2 \mathrm{~min}$. The systolic and diastolic pressure records were digitized through an analog-digital interface (PowerLab 400; ADInstruments) for offline analysis with Chart 4.0 software (ADInstruments). Pressure versus volume curves were obtained at varying loads in systole and diastole, and data were analyzed by calculating the integral of the curves using MATLAB software version 7.0.

\section{Histomorphometry}

Myocardial tissue was fixed in $4 \%$ paraformaldehyde for $24 \mathrm{~h}$ and paraffin-embedded. Six-micrometer sections were stained with Sirius red and scanned to obtain digital images of the entire heart. The percentage of left ventricular area occupied by the infarct was calculated by dividing the area stained in red (collagen fibers) by the total area of the left ventricle. These areas were quantified using Image Pro Plus software version 7.0.1 in three regions of the heart (apex, middle portion, and base). Results are shown as an average of the three values.

\section{Statistics}

Data are shown as mean \pm standard deviation. Echocardiography data were analyzed using two-way ANOVA, while Langendorff and histomorphometric data were analyzed using one-way ANOVA. Bonferroni's post test was applied in both cases and $p<0.05$ was considered significant. Graph Pad Prism software version 6.0 was used for all analyses.

\section{Results}

\section{Isolation and characterization of human and rat CDC}

We obtained CDC from human discarded myocardial tissue and rat hearts. Between 10 and 15 days after cell isolation from human and rat tissues, small, round, PBCs appeared on top of adherent fibroblast-like cells derived from explants. PBCs were collected and cultured for 2 days on a nonadherent plate, where they formed cardiospheres which were then transferred to adherent plates, giving rise to CDC (Fig. 1a). We obtained cultures of explants derived from human (Fig. 1b) and rat (Fig. 1e) tissues. Fig. 1c and $f$ show representative images of cardiospheres derived from human and rat hearts, respectively. Both hCDC (Fig. 1d) and rCDC (Fig. 1g) were successfully isolated and 

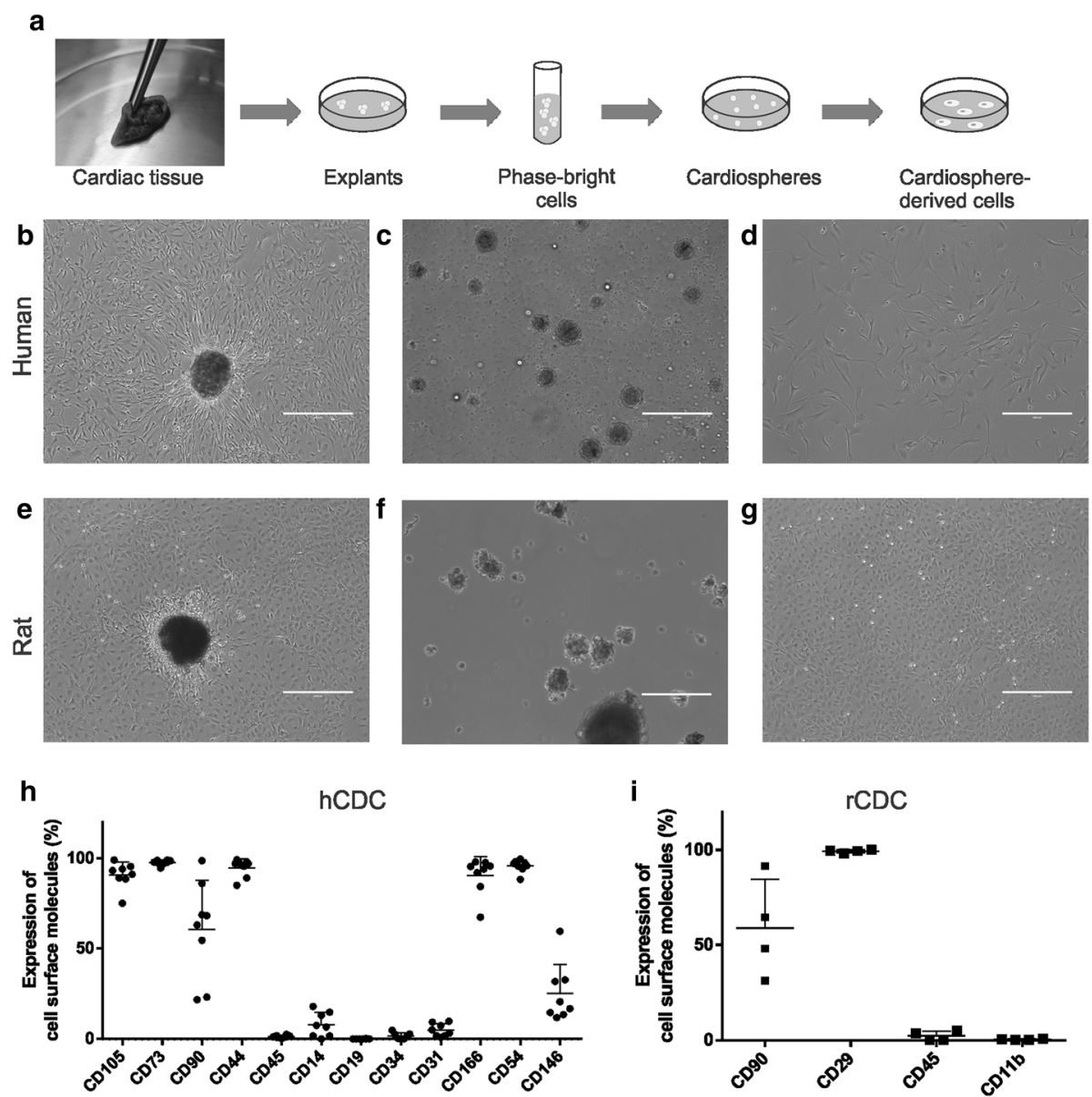

Fig. 1 Isolation and characterization of CDC. a Cardiac tissue was minced into small fragments and plated as explants. PBCs were collected and cultured on nonadherent plates, forming cardiospheres. CDC were generated by transferring cardiospheres to adherent plates. Representative images of human and rat explants $(\mathbf{b}, \mathbf{e})$, cardiospheres $(\mathbf{c}, \mathbf{f})$ and $\operatorname{CDC}(\mathbf{d}, \mathbf{g})$. Surface molecule expression was characterized by flow cytometry in hCDC (h) and rCDC (i). Note the large standard deviations for CD90 in both hCDC and rCDC, representing heterogeneous expression of this molecule. $h C D C$ human cardiosphere-derived cell, $r C D C$ rat cardiosphere-derived cell

expanded until the third passage. hCDC expressed mesenchymal markers (CD105, CD73, CD90) and adhesion molecules (CD54, CD146, CD166) and showed low expression of hematopoietic and endothelial markers (CD45, CD14, CD19, CD34, CD31) when analyzed by flow cytometry (Fig. $1 \mathrm{~h} ; n=8$ ). Similarly, rCDC expressed high levels of mesenchymal markers (CD90.1, CD29), whereas contamination by hematopoietic cells (CD45, CD11b) was minimal (Fig. 1i; $n=4$ ).

\section{Transduction and tracking of CDC in infarcted myocardium}

Previous work has identified CDC as endogenous cardiac progenitor cells with regenerative potential in models of acute MI $[6,9,22,23]$. We investigated this potential in a rat chronic model by the injection of CDC 60 days post MI. Figure 2a shows a rat infarcted heart 3 days after cell therapy. Cells were present at the injection site. The bioluminescent signal of CDC-Luc2 was detected in the thoracic region until day 7 post injection (Fig. 2d, e). Radiance quantification demonstrated a $98.8 \%$ decrease in mean bioluminescent signal at 5-7 days after injection of hCDC in immunosuppressed rats (D1: $2.54 \pm 2.52 \times 10^{5}$, D3: $1.49 \pm 1.15 \times 10^{5}, \mathrm{D} 5-7: 3.21 \pm 2.34 \times 10^{3} \mathrm{p} / \mathrm{sec} / \mathrm{cm}^{2} / \mathrm{sr}$ ) (Fig. 2b). Syngeneic rCDC presented an $87.2 \%$ reduction in signal over the same period (D1: $4.63 \pm 2.59 \times 10^{4}$, D3: $1.82 \pm 1.04 \times 10^{4}, \quad$ D $\left.5-7: \quad 5.95 \pm 0.87 \times 10^{3} \mathrm{p} / \mathrm{sec} / \mathrm{cm}^{2} / \mathrm{sr}\right)$ (Fig. 2c).

\section{Cardiac functional evaluation post CDC treatment}

To evaluate potential benefits of hCDC and $\mathrm{rCDC}$ therapy, we performed in-vivo and ex-vivo analyses of cardiac function. Figure 3 and Table 1 show the results of echocardiographic examinations. We observed no differences in EDV (Fig. 3a), EF (Fig. 3b), ESV (Fig. 3c), or FAC (Fig. 3d) between hCDC, rCDC, and placebotreated animals at all time points assessed. In these animals, all tested parameters of cardiac function were 
a
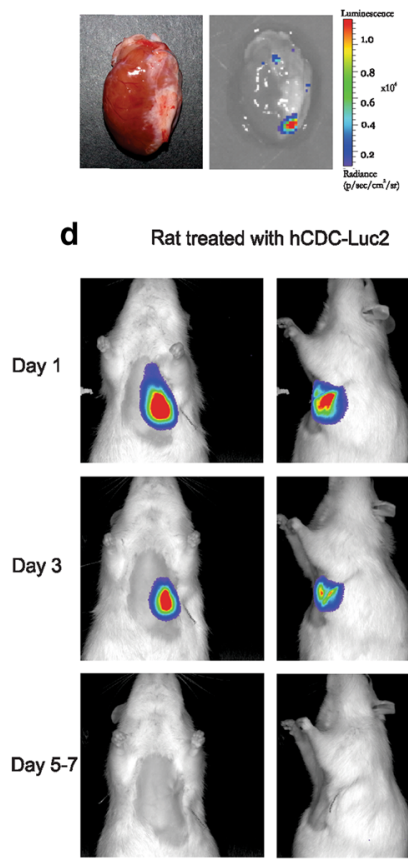
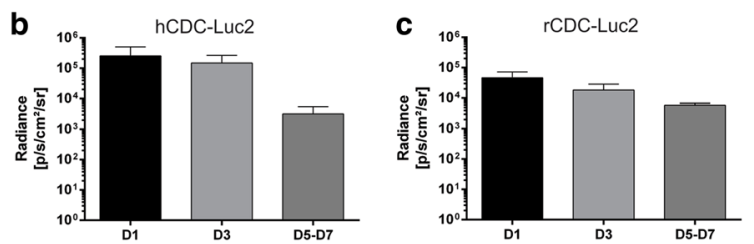

e

Rat treated with rCDC-Luc2
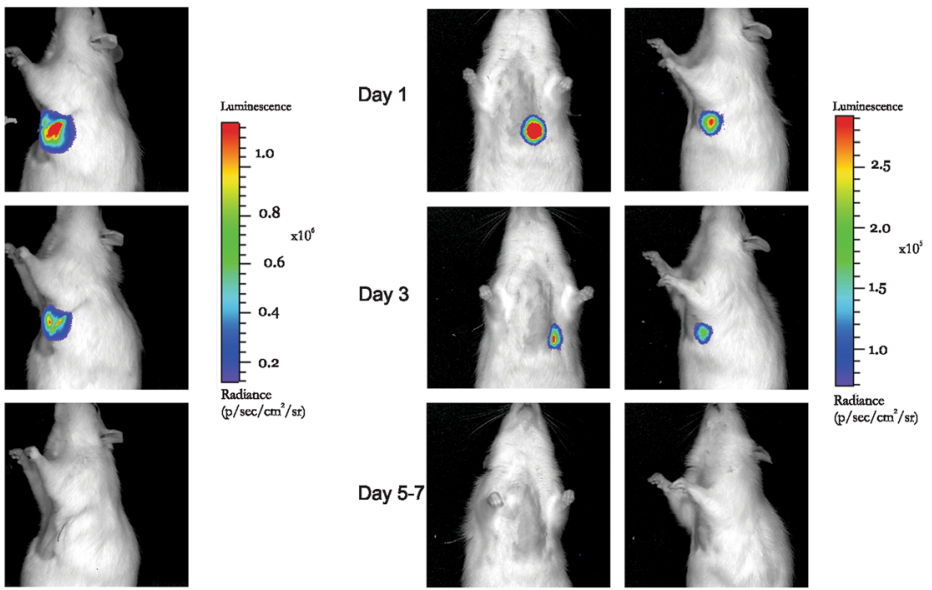

Fig. 2 CDC tracking by bioluminescence. a Ex-vivo image of a rat heart after echocardiography-guided intramyocardial injection of transduced CDC. Signal is located on the border zone of the infarct. Quantification of luminescent signal in rats injected with hCDC (b) or rCDC (c). d, e In-vivo cell tracking shows luminescent signal on the precordial region of infarcted rat. Luminescence was detected until 5-7 days after injection. Color scales are shown in units of radiance, and quantification data are plotted on a log scale (Color figure online). hCDC human cardiospherederived cell, rCDC rat cardiosphere-derived cell

significantly lower than those observed in shamoperated animals.

To investigate the hemodynamic performance of isolated hearts after cell therapy with $\mathrm{CDC}$, we used a modified Langendorff apparatus. The diastolic pressure versus volume curves of infarcted animals shifted downwards when compared with the sham-operated group (Fig. 3e). The same was observed for the systolic curve (Fig. 3f). The area under the curves was analyzed and no differences were observed between placebo and celltreated animals (Fig. 3g, h).

To assess whether CDC treatment reduced the infarcted area, we performed morphometry with Sirius red staining. Figure 3i shows the sham-operated heart with viable muscle (light staining), whereas the infarcted heart shows collagen fibers (dark staining), indicating scar areas. The percentage of fibrosis was quantified in the left ventricle after CDC cell therapy. Treated animals (hCDC or $\mathrm{rCDC}$ ) had no improvement in the amount of viable cardiac muscle when compared with the placebo group (Fig. 3j). The sham-operated group had significantly less fibrotic tissue than the other groups.

\section{Discussion}

The present study evaluated the efficacy of late CDC treatment in a rat model of HF. We chose to base our work on a late treatment because it more closely resembles the situation of most HF patients who develop the disease over the course of many years. Moreover, in advanced stages there is no definitive therapy other than a heart transplant. To date, the potential benefits of CDC therapy had not been evaluated in a rat chronic model. We reproduced in detail all of the steps described previously for stem cell isolation, identification, and injection. Despite these efforts, we show that CDC therapy did not improve cardiac function or reduce scarring in this animal model.

We isolated, expanded, and characterized CDC derived from discarded human tissue or rat hearts using established procedures $[6,9,15]$. Cells had the immunophenotypic profile described previously $[6,9]$ except for low ckit expression. The low expression of c-kit observed in our work should not have posed a problem, because recent work has shown no correlation between the presence of c-kit and the regenerative efficacy of CDC [24]. Much like the CDC used in previous studies $[16,17]$, our cells expressed heterogeneous levels of CD90.

We injected CDC into the peri-infarcted area of the myocardium, because this was the most common delivery route in rodent acute MI models treated with CDC $[6,22,24,25]$. Several authors have reported that a majority of injected cells die a few days after the procedure, 

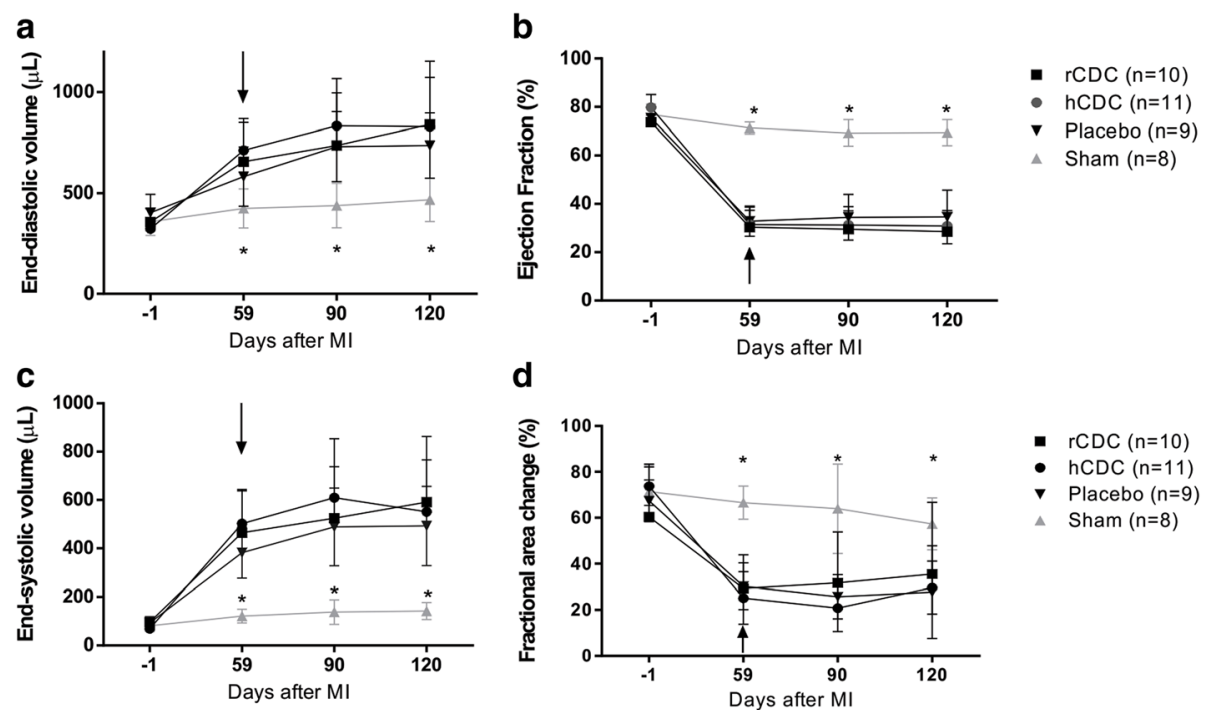

d

Placebo $(n=9)$
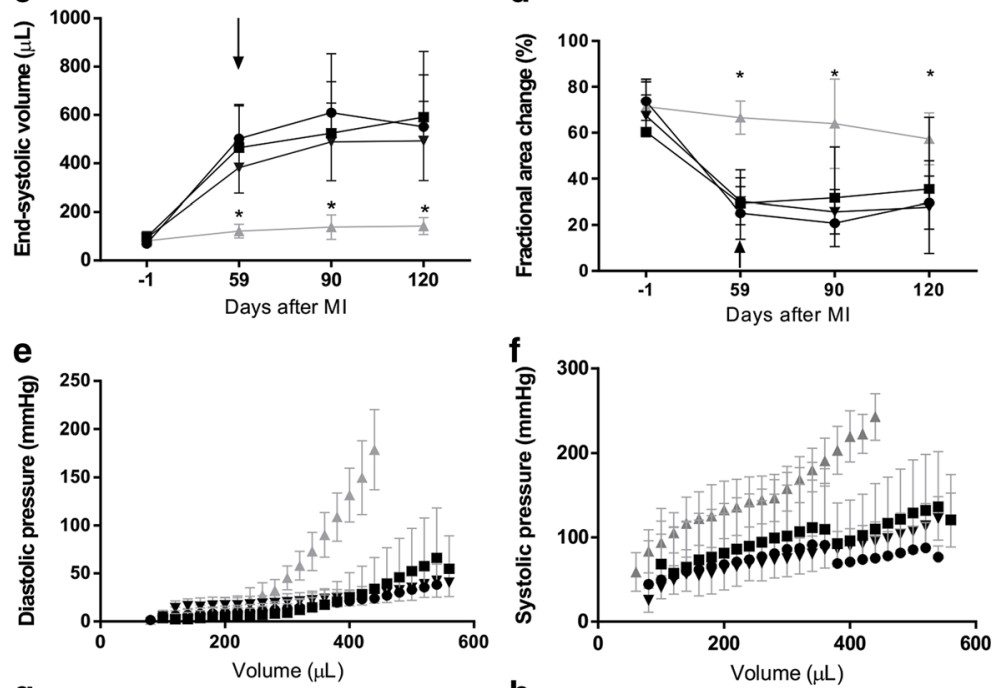

- $\operatorname{rCDC}(n=10)$

- $\operatorname{hCDC}(n=11)$

- Placebo $(n=9)$

$\Delta$ Sham $(n=8)$

g

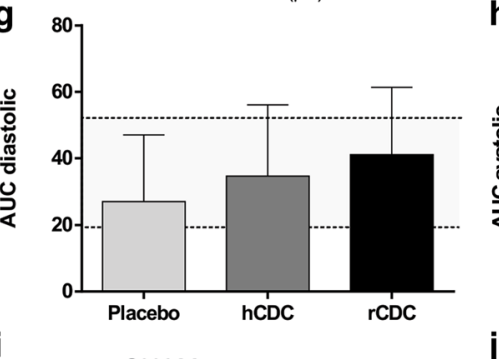

i

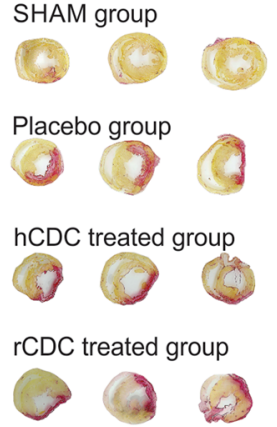

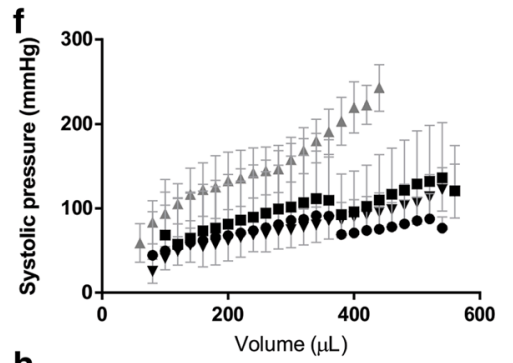

h

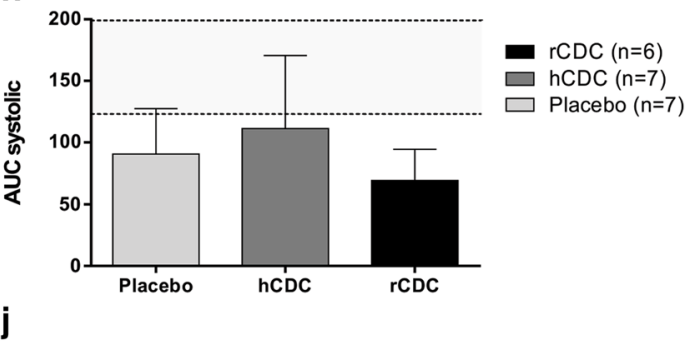

$\operatorname{rCDC}(n=6)$

- $\operatorname{hCDC}(n=7)$

Placebo $(n=7)$

Sham $(n=4)$

Fig. 3 Cardiac function evaluation after CDC therapy. a EDV, (b) EF, (c) ESV, and (d) FAC. Arrows, rats treated 1 day after the data were collected. No differences were found when placebo, rCDC, and hCDC groups were compared. Sham-operated rats had significantly lower values of EDV and ESV and higher values of EF and FAC when compared with the infarcted groups. Considering equal volumes, infarcted groups had lower values of diastolic (e) and systolic (f) pressures when compared with sham-operated rats, suggesting cavity dilation and systolic dysfunction respectively. The area under the diastolic ( $\mathbf{g}$ ) and systolic (h) curves (AUC) was calculated. There were no differences between placebo and celltreated groups. i Representative images of serial heart tissue slices stained by Sirius Red from sham, infarcted animals treated with CDC and placebo. Fibrotic tissue is marked in red. $\mathbf{j}$ Quantification of fibrotic area showed a significant increase in infarcted groups when compared with sham-operated rats. Shaded area represents values belonging to the sham group. No differences were observed between placebo, rCDC, and hCDC groups. ${ }^{*} p<0.05$ when comparing sham animals with infarcted animals (Color figure online). $h C D C$ human cardiosphere-derived cell, $r C D C$ rat cardiosphere-derived cell 
Table 1 Cardiac function of experimental groups

\begin{tabular}{|c|c|c|c|c|c|}
\hline \multirow[b]{2}{*}{ Parameter } & \multirow[b]{2}{*}{ Time (days) } & \multicolumn{4}{|c|}{ Experimental group } \\
\hline & & Sham $(n=8)$ & Placebo $(n=9)$ & $\mathrm{hCDC}(n=11)$ & $\operatorname{rCDC}(n=10)$ \\
\hline \multirow[t]{4}{*}{ Ejection fraction (\%) } & -1 & $76.85 \pm 4.24$ & $75.50 \pm 1.48$ & $79.83 \pm 5.34$ & $72.97 \pm 3.69$ \\
\hline & 59 & $70.72 \pm 2.08$ & $32.88 \pm 6.28^{*}$ & $31.48 \pm 7.26^{*}$ & $30.39 \pm 6.97^{*}$ \\
\hline & 90 & $69.33 \pm 5.45$ & $34.49 \pm 9.48^{*}$ & $31.26 \pm 7.66^{*}$ & $29.56 \pm 7.59^{*}$ \\
\hline & 120 & $69.44 \pm 5.36$ & $34.62 \pm 11.08^{*}$ & $30.89 \pm 6.39^{*}$ & $28.58 \pm 7.68^{*}$ \\
\hline \multirow[t]{4}{*}{ End-diastolic volume $(\mu \mathrm{l})$} & -1 & $358.8 \pm 68.61$ & $383.7 \pm 80.47$ & $323.2 \pm 39.71$ & $357.7 \pm 65.29$ \\
\hline & 59 & $424.4 \pm 97.15$ & $643.1 \pm 98.04^{*}$ & $712.3 \pm 137.9^{*}$ & $656.8 \pm 213.1^{*}$ \\
\hline & 90 & $438.7 \pm 110.40$ & $730.6 \pm 172.90^{*}$ & $833.3 \pm 234.3^{*}$ & $736.3 \pm 259.8^{*}$ \\
\hline & 120 & $467.7 \pm 108.2$ & $736.20 \pm 161.6^{*}$ & $830 \pm 243.9^{*}$ & $840.2 \pm 313.4^{*}$ \\
\hline \multirow[t]{4}{*}{ End-systolic volume $(\mu \mathrm{l})$} & -1 & $80.91 \pm 22.78$ & $93.20 \pm 25.63$ & $69.52 \pm 16.13$ & $96.06 \pm 18.68$ \\
\hline & 59 & $121.4 \pm 28.45$ & $382.4 \pm 105.2^{*}$ & $502 \pm 135.8^{*}$ & $464.40 \pm 179.3^{*}$ \\
\hline & 90 & $137.5 \pm 50.67$ & $488.80 \pm 160.5^{*}$ & $609.2 \pm 244.8^{*}$ & $525 \pm 212.6^{*}$ \\
\hline & 120 & $142 \pm 34.97$ & $492.5 \pm 163.6^{*}$ & $551 \pm 214.9^{*}$ & $591.40 \pm 271.3^{*}$ \\
\hline \multirow[t]{4}{*}{ Fractional area change (\%) } & -1 & $71.38 \pm 11.53$ & $67.38 \pm 9.06$ & $73.75 \pm 8.34$ & $66.05 \pm 8.87$ \\
\hline & 59 & $66.58 \pm 7.23$ & $30.22 \pm 10.12^{*}$ & $25.15 \pm 11.40^{*}$ & $24.90 \pm 10.79^{*}$ \\
\hline & 90 & $63.95 \pm 19.47$ & $25.70 \pm 9.56^{*}$ & $20.78 \pm 10.16^{*}$ & $25.85 \pm 8.36^{*}$ \\
\hline & 120 & $57.33 \pm 11.30$ & $27.71 \pm 20.11^{*}$ & $29.65 \pm 11.46^{*}$ & $25.47 \pm 9.69^{*}$ \\
\hline
\end{tabular}

Data presented as mean \pm SD. Day -1 shows baseline values (before myocardial infarction) for all groups. Day 59 shows data 1 day before treatment with placebo, hCDC, or rCDC

${ }^{*} p<0.05$ compared with sham-operated group

$h C D C$ human cardiosphere-derived cell, $r C D C$ rat cardiosphere-derived cell

and that $10 \%$ or fewer of the cells remain in the heart [11]. Despite the chosen cell dose ( 2 million cells $/ \mathrm{kg}$ of body weight) being higher than the dose administered in the CADUCEUS clinical trial $(178,000-357,000$ cells $/ \mathrm{kg}$ of body weight), our treatment resulted in low cell engraftment and retention levels, comparable with those described previously [14]. To exclude the possibility that the expression of luciferase 2 could alter the quality and a putative therapeutic effect of $\mathrm{CDC}$, the tracking assays with transduced $\mathrm{CDC}$ were performed in a separate group of animals. One limitation of our study was the delivery of cells in only two injection sites. Although injected cells are known to migrate from the site of injection, we cannot exclude that multiple sites of injection are necessary to improve cardiac function.

Several groups have reported improvements in cardiac function after CDC therapy in rodent models [6, 9, 22-26]. Acute treatment of small animals with $\mathrm{CDC}$ reduces scar size $[22,25,26]$, increases $\operatorname{EF}[6,9,23,24,26]$ and muscle viability $[9,23]$, and decreases EDV as well as ESV [25]. On the other hand, chronic treatment performed in large animal models yielded subtle or negative results [10-12]. In 2009, Marban's group showed that placebo-treated and CDCtreated pigs using the intracoronary route had similar values of EF [10]. In a later study, the same group reported preservation of function, but not improvement, when administering intramyocardial injection of CDC [11]. Takehara et al. [12] achieved improved ventricular function in post-
MI pigs using a combination of bFGF gels and CDC, an approach less translatable to the clinical setting; however, administration of CDC to pigs without additional growth factors resulted in only slight improvement to the EF.

In preclinical experiments performed in small animals, the best results have been obtained when cell therapy has been administered immediately after coronary occlusion, whereas the benefit obtained when using chronic models in large animals has been quite modest. Despite this limited success achieved in animal model studies, CDC were administered to humans 2-4 months after $\mathrm{MI}$ in the CADUCEUS phase I clinical trial. One year after treatment, the trial reported MRI results showing a decrease in scar tissue. Nevertheless, a recent metaanalysis of several clinical trials reported that the CDC used in CADUCEUS did not yield benefits in terms of clinical events or changes in cardiac function [18]. Similarly, all other cell therapies evaluated to date have been of limited benefit to MI patients. The disappointing results from human trials clearly do not reflect the improvements observed in acute animal models.

Despite our efforts to closely reproduce best-practice conditions for CDC therapy, evaluation of the animals showed no differences in cardiac function between groups receiving human cells, rat cells, or a placebo. This lack of difference was also evident with regards to scar size. Previous work in mice has similarly failed to 
demonstrate any improvement after CDC treatment in an acute MI model, in spite of achieving long-term engraftment. In that study, functional evaluations were performed by several methods, such as echocardiogram, hemodynamic analysis, MRI, and positron emission tomography [14]. In addition, other groups have cast doubt on whether CDC indeed constitute a source of stem cells with cardiomyogenic potential $[13,15]$.

In light of these discrepant findings in animal models, we suggest that it is time for a cautious step back. Pending issues-such as the differentiation potential of CDC, the existence of $\mathrm{CDC}$ subpopulations, and new approaches to the isolation of cardiac stem cells [27] - must be addressed before the potential therapeutic effect of CDC in heart disease can be realized.

\section{Conclusion}

Treatment with CDC did not improve heart function or prevent heart chamber dilatation in rats with $\mathrm{MI}$ and cardiac remodeling. Our study challenges the effectiveness of CDC in post-ischemic HF.

\begin{abstract}
Abbreviations
bFGF: Basic fibroblast growth factor; BSA: Bovine serum albumin; CABG: Coronary artery bypass; CADUCEUS: CArdiosphere-Derived aUtologous StemCElls to reverse ventricUlar dySfunction; CDC: Cardiosphere-derived cells; ECG: Electrocardiography; EDV: End-diastolic volume; EF: Ejection fraction; ESV: End-systolic volume; FAC: Fractional area change; hCDC: Human cardiosphere-derived cells; HF: Heart failure; LAD: Left anterior descending; LIF: Leukemia inhibitory factor; MI: Myocardial infarction; PBC: Phase-bright cell; PBS: Phosphate buffer saline; rCDC: Rat human cardiosphere-derived cells
\end{abstract}

\section{Acknowledgements}

The authors would like to thank Michelle Lopes Araújo for her help with myocardial infarction experiments.

\section{Funding}

This publication and its reagents, techniques, and experimental models were supported by funding from Conselho Nacional de Desenvolvimento Científico e Tecnológico (CNPq), Ministry of Health—Department of Science and Technology, and Fundação Carlos Chagas Filho de Amparo à Pesquisa do Rio de Janeiro (FAPERJ).

\section{Availability of data and materials}

All data generated or analyzed in this study are included in this published article.

\section{Authors' contributions}

THK-B participated in the experimental study design, all steps of data collection, analysis and interpretation, and also the writing of this manuscript. ARdC contributed to the experimental study design, and collected in-vitro datasets. RAQB participated in the collection of in-vitro datasets and contributed to the writing of this manuscript. BF was responsible for Langendorff perfusion experiments and also contributed to the writing of the manuscript. FCPM participated in viral transduction of cells. DSdS contributed to bioluminescence tracking and to echocardiogram-guided cell injection. IPR performed and analyzed echocardiograms. GS performed myocardial infarction on all animals. GVB was responsible for echocardiogramguided cell injection. STdC performed histological examination of infarcted hearts after treatment by immunocytochemistry. JORB was responsible for patient selection and provision of study material. JdAP contributed to the study design, bioluminescence tracking, and writing of this manuscript. $A B C$ contributed to the experimental study design, supervised dataset collection and interpretation, and also participated in the writing of the manuscript. $\mathrm{ACCdC}$ was responsible for the project execution, defining the experimental study design, and discussing and interpreting the collected data. All writers read and approved the final manuscript.

\section{Competing interests}

The authors declare that they have no competing interests.

\section{Consent for publication}

Not applicable.

\section{Ethics approval and consent to participate}

This study was approved by the local institutional research ethics boards from the National Institute of Cardiology under number 059270/2012, where human heart samples were collected after informed consent, and the Federal University of Rio de Janeiro where all animal procedures were carried out in accordance with the Guide for the Care and Use of Laboratory Animals $(\mathrm{NIH})$ and approved by the institutional ethics committee under number IBCCF 026/2008. The National Institute of Science and Technology for Regenerative Medicine, The Institute of Biophysics Carlos Chagas Filho, and the National Center for Structural Biology and Bioimaging - CENABIO are all part of the Federal University of Rio de Janeiro and thus ethical approval is obtained from only one of these centers, in our case the Institute of Biophysics Carlos Chagas Filho.

\section{Author details}

${ }^{1}$ Institute of Biophysics Carlos Chagas Filho, Federal University of Rio de Janeiro, Av. Carlos Chagas Filho, n³73, room G2-053, CEP:21941-902 Rio de Janeiro, RJ, Brazil. ${ }^{2}$ National Institute of Cardiology, Rua das Laranjeiras, $n^{\circ}$ 374-Laranjeiras, CEP:22240-006 Rio de Janeiro, RJ, Brazil. ${ }^{3}$ National Center for Structural Biology and Bioimaging-CENABIO, Federal University of Rio de Janeiro, Av. Carlos Chagas Filho, n³73, buiding M, CEP:21941-902 Rio de Janeiro, RJ, Brazil. ${ }^{4}$ National Institute of Science and Technology for Regenerative Medicine, Av. Carlos Chagas Filho, n³73, CEP:21941-902 Rio de Janeiro, RJ, Brazil.

Received: 3 November 2016 Revised: 10 January 2017 Accepted: 13 January 2017 Published online: 15 February 2017

\section{References}

1. Pocock SJ, Wang D, Pfeffer MA, Yusuf S, McMurray JJ, Swedberg KB, Ostergren J, Michelson EL, Pieper KS, Granger CB. Predictors of mortality and morbidity in patients with chronic heart failure. Eur Heart J. 2006;27:65-75.

2. Beltrami AP, Barlucchi L, Torella D, Baker M, Limana F, Chimenti S, Kasahara H, Rota M, Musso E, Urbanek K, Leri A, Kajstura J, Nadal-Ginard B, Anversa P. Adult cardiac stem cells are multipotent and support myocardial regeneration. Cell. 2003;114:763-76.

3. Bearzi C, Rota M, Hosoda T, Tillmanns J, Nascimbene A, De Angelis A, Yasuzawa-Amano S, Trofimova I, Siggins RW, Lecapitaine N, Cascapera S, Beltrami AP, D'Alessandro DA, Zias E, Quaini F, Urbanek K, Michler RE, Bolli R, Kajstura J, Leri A, Anversa P. Human cardiac stem cells. Proc Natl Acad Sci U S A. 2007;104:14068-73.

4. Messina E, De Angelis L, Frati G, Morrone S, Chimenti S, Fiordaliso F, Salio M, Battaglia M, Latronico MV, Coletta M, Vivarelli E, Frati L, Cossu G, Giacomello A. Isolation and expansion of adult cardiac stem cells from human and murine heart. Circ Res. 2004;95:911-21.

5. Oh H, Bradfute SB, Gallardo TD, Nakamura T, Gaussin V, Mishina Y, Pocius J, Michael LH, Behringer RR, Garry DJ, Entman ML, Schneider MD. Cardiac progenitor cells from adult myocardium: homing, differentiation, and fusion after infarction. Proc Natl Acad Sci U S A. 2003;100:12313-8.

6. Smith RR, Barile L, Cho HC, Leppo MK, Hare JM, Messina E, Giacomello A, Abraham MR, Marban E. Regenerative potential of cardiosphere-derived cells expanded from percutaneous endomyocardial biopsy specimens. Circulation. 2007;115:896-908.

7. Chimenti I, Smith RR, Li TS, Gerstenblith G, Messina E, Giacomello A, Marban $E$. Relative roles of direct regeneration versus paracrine effects of human cardiosphere-derived cells transplanted into infarcted mice. Circ Res. 2010; 106:971-80

8. Davis DR, Zhang Y, Smith RR, Cheng K, Terrovitis J, Malliaras K, Li TS, White A, Makkar R, Marban E. Validation of the cardiosphere method to culture cardiac progenitor cells from myocardial tissue. PLoS One. 2009;4, e7195.

9. Davis DR, Kizana E, Terrovitis J, Barth AS, Zhang Y, Smith RR, Miake J, Marban E. Isolation and expansion of functionally-competent cardiac progenitor cells directly from heart biopsies. J Mol Cell Cardiol. 2010;49:312-21. 
10. Johnston PV, Sasano T, Mills K, Evers R, Lee ST, Smith RR, Lardo AC, Lai S, Steenbergen C, Gerstenblith G, Lange R, Marban E. Engraftment, differentiation, and functional benefits of autologous cardiosphere-derived cells in porcine ischemic cardiomyopathy. Circulation. 2009;120:1075-83. 7 p following 1083.

11. Lee ST, White AJ, Matsushita S, Malliaras K, Steenbergen C, Zhang Y, Li TS, Terrovitis J, Yee K, Simsir S, Makkar R, Marban E. Intramyocardial injection of autologous cardiospheres or cardiosphere-derived cells preserves function and minimizes adverse ventricular remodeling in pigs with heart failure post-myocardial infarction. J Am Coll Cardiol. 2011;57:455-65.

12. Takehara N, Tsutsumi Y, Tateishi K, Ogata T, Tanaka H, Ueyama T, Takahash T, Takamatsu T, Fukushima M, Komeda M, Yamagishi M, Yaku H, Tabata Y, Matsubara $\mathrm{H}, \mathrm{Oh} \mathrm{H}$. Controlled delivery of basic fibroblast growth factor promotes human cardiosphere-derived cell engraftment to enhance cardiac repair for chronic myocardial infarction. J Am Coll Cardiol. 2008;52:1858-65.

13. Shenje $L T$, Field $L$, Pritchard CA, Guerin CJ, Rubart M, Soonpaa MH, Ang KL, Galinanes M. Lineage tracing of cardiac explant derived cells. PLoS One. 2008;3, e1929.

14. Li Z, Lee A, Huang M, Chun H, Chung J, Chu P, Hoyt G, Yang P, Rosenberg J, Robbins RC, Wu JC. Imaging survival and function of transplanted cardiac resident stem cells. J Am Coll Cardiol. 2009;53:1229-40.

15. Andersen DC, Andersen P, Schneider M, Jensen HB, Sheikh SP. Murine "cardiospheres" are not a source of stem cells with cardiomyogenic potential. Stem Cells. 2009;27:1571-81.

16. Makkar RR, Smith RR, Cheng K, Malliaras K, Thomson LE, Berman D, Czer LS, Marban L, Mendizabal A, Johnston PV, Russell SD, Schuleri KH, Lardo AC, Gerstenblith G, Marban E. Intracoronary cardiosphere-derived cells for heart regeneration after myocardial infarction (CADUCEUS): a prospective, randomised phase 1 trial. Lancet. 2012;379:895-904.

17. Malliaras K, Makkar RR, Smith RR, Cheng K, Wu E, Bonow RO, Marban L, Mendizabal A, Cingolani E, Johnston PV, Gerstenblith G, Schuleri KH, Lardo AC, Marban E. Intracoronary cardiosphere-derived cells after myocardial infarction: evidence of therapeutic regeneration in the final 1-year results of the CADUCEUS trial (CArdiosphere-Derived aUtologous stem CElls to reverse ventricUlar dySfunction). J Am Coll Cardiol. 2014;63:110-22.

18. Gyongyosi M, Wojakowski W, Lemarchand P, Lunde K, Tendera M, Bartunek J, Marban E, Assmus B, Henry TD, Traverse JH, Moye L, Suerder D, Corti R, Huikuri HV, Miettinen JA, Woehrle J, Obradovic S, Roncalli J, Malliaras K, Pokushalov E, Romanov A, Kastrup J, Bergmann MW, Atsma D, Diederichsen AC, Edes I, Benedek I, Benedek T, Pejkov H, Nyolczas N, Pavo N, Bergler-Klein J, Pavo IJ, Sylven C, Berti S, Navarese EP, Maurer GM. Meta-Analysis of Cellbased CaRdiac stUdiEs (ACCRUE) in patients with acute myocardial infarction based on individual patient data. Circ Res. 2015;116:1346-60.

19. Benavides-Vallve C, Corbacho D, Iglesias-Garcia O, Pelacho B, Albiasu E, Castano S, Munoz-Barrutia A, Prosper F, Ortiz-de-Solorzano C. New strategies for echocardiographic evaluation of left ventricular function in a mouse model of long-term myocardial infarction. PLoS One. 2012;7, e41691.

20. Yeh YC, Lee WY, Yu CL, Hwang SM, Chung MF, Hsu LW, Chang Y, Lin WW, Tsai MS, Wei HJ, Sung HW. Cardiac repair with injectable cell sheet fragments of human amniotic fluid stem cells in an immune-suppressed rat model. Biomaterials. 2010;31:6444-53.

21. Passipieri JA, Kasai-Brunswick TH, Suhett G, Martins AB, Brasil GV, Campos DB, Rocha NN, Ramos IP, Mello DB, Rodrigues DC, Christie BB, Silva-Mendes BJ, Balduino A, Sa RM, Lopes LM, Goldenberg RC, Campos de Carvalho AC, Carvalho AB. Improvement of cardiac function by placenta-derived mesenchymal stem cells does not require permanent engraftment and is independent of the insulin signaling pathway. Stem Cell Res Ther. 2014;5:102.

22. Malliaras K, Li TS, Luthringer D, Terrovitis J, Cheng K, Chakravarty T, Galang G, Zhang Y, Schoenhoff F, Van Eyk J, Marban L, Marban E. Safety and efficacy of allogeneic cell therapy in infarcted rats transplanted with mismatched cardiosphere-derived cells. Circulation. 2012;125:100-12.

23. Mishra R, Vijayan K, Colletti EJ, Harrington DA, Matthiesen TS, Simpson D, Goh SK, Walker BL, Almeida-Porada G, Wang D, Backer CL, Dudley Jr SC, Wold LE, Kaushal S. Characterization and functionality of cardiac progenitor cells in congenital heart patients. Circulation. 2011;123:364-73.

24. Cheng K, Ibrahim A, Hensley MT, Shen D, Sun B, Middleton R, Liu W, Smith $\mathrm{RR}$, Marban E. Relative roles of CD90 and c-kit to the regenerative efficacy of cardiosphere-derived cells in humans and in a mouse model of myocardial infarction. J Am Heart Assoc. 2014;3, e001260.

25. Carr CA, Stuckey DJ, Tan JJ, Tan SC, Gomes RS, Camelliti P, Messina E, Giacomello A, Ellison GM, Clarke K. Cardiosphere-derived cells improve function in the infarcted rat heart for at least 16 weeks —an MRI study. PLoS One. 2011;6, e25669.

26. Cheng K, Malliaras $K$, Smith RR, Shen D, Sun B, Blusztajn A, Xie Y, Ibrahim A, Aminzadeh MA, Liu W, Li TS, De Robertis MA, Marban L, Czer LS, Trento A, Marban E. Human cardiosphere-derived cells from advanced heart failure patients exhibit augmented functional potency in myocardial repair. JACC Heart Fail. 2014;2:49-61.

27. Zhang $Y$, Sivakumaran P, Newcomb AE, Hernandez D, Harris N, Khanabdali R, Liu GS, Kelly DJ, Pebay A, Hewitt AW, Boyle A, Harvey R, Morrison WA, Elliott DA, Dusting GJ, Lim SY. Cardiac repair with a novel population of mesenchymal stem cells resident in the human heart. Stem Cells. 2015:33:3100-13.

\section{Submit your next manuscript to BioMed Central and we will help you at every step:}

- We accept pre-submission inquiries

- Our selector tool helps you to find the most relevant journal

- We provide round the clock customer support

- Convenient online submission

- Thorough peer review

- Inclusion in PubMed and all major indexing services

- Maximum visibility for your research

Submit your manuscript at www.biomedcentral.com/submit
Ciomed Central 